\title{
Effect of Land Use Management Patterns on Mineralization Kinetics of Soil Organic Carbon in Mount Bambouto Caldera Area of Cameroon
}

\author{
Formeluh Abraham Toh ${ }^{*}$, Lawrence Monah Ndam², \\ Tsi Evaristus Angwafo ${ }^{3}$, Ngosong Christopher ${ }^{2}$ \\ ${ }^{1}$ Dschang School of Agriculture and Environmental Sciences, University of Dschang, Dschang, Cameroon \\ ${ }^{2}$ Faculty of Agriculture and Veterinary Medicine, University of Buea, South West Region, Buea, Cameroon \\ ${ }^{3}$ Department of Fundamental Science, HTTTC, Bambili, University of Bamenda, Bamenda, Cameroon \\ Email: ${ }^{*}$ formeluhat@gmail.com
}

How to cite this paper: Toh, F.A., Ndam, L.M., Angwafo, T.E. and Christopher, N. (2020) Effect of Land Use Management Patterns on Mineralization Kinetics of Soil Organic Carbon in Mount Bambouto Caldera Area of Cameroon. Open Journal of Soil Science, 10, 391-409.

https://doi.org/10.4236/ojss.2020.109021

Received: August 15, 2020

Accepted: September 20, 2020

Published: September 23, 2020

Copyright $\odot 2020$ by author(s) and Scientific Research Publishing Inc. This work is licensed under the Creative Commons Attribution International License (CC BY 4.0).

http://creativecommons.org/licenses/by/4.0/

(c) (i) Open Access

\begin{abstract}
Soil organic carbon (SOC) mineralization was carried out on soil samples collected from two depths: $0-20 \mathrm{~cm}$ and $20-40 \mathrm{~cm}$ for all land use (LU) types (grasslands, croplands, natural forest/fallow lands, cocoa/palm plantations, and settlement/agro-forests). Microbiological analyses were carried out by measuring microbial activity in $40 \mathrm{~g}$ of dried soil samples wetted to $60 \%$ water holding capacity and incubated at $27^{\circ} \mathrm{C}$. Carbon dioxide $\left(\mathrm{CO}_{2}\right)$ emission was measured for 10 weeks using a $\mathrm{CO}_{2}$ trap. Descriptive and graphical analyses of $\mathrm{CO}_{2}$ respiration were done using $\mathrm{CO}_{2}$ emission data. Models were developed to describe $\mathrm{CO}_{2}$ respiration and the first order kinetic model provided best fit to $\mathrm{C}$-mineralization. Potentially mineralizable carbon $\left(\mathrm{C}_{\mathrm{o}}\right)$ and $\mathrm{C}$-mineralization rate were higher in grasslands than other LU types, indicating a higher rate of microbial activity and carbon cycling. Metabolic quotient was higher in forest/fallow lands and reflects greater stress of the microbial community and a high requirement of maintenance energy. Grasslands enhanced more SOC accumulation and decomposition, suggesting a better carbon sink than other land use and management systems (LUMS). Microbial biomass carbon $(\mathrm{MBC})$ and microbial biomass nitrogen $(\mathrm{MBN})$ varied across LU patterns with maximum values in grasslands and minimum values in natural forest/fallow lands insinuating better soil quality for grasslands. $\mathrm{MBC}$ and SOC positively correlated with $\mathrm{C}_{\mathrm{o}}$ and $\mathrm{C}$-mineralization, which intimates that $\mathrm{C}$-mineralization is influenced by availability of $\mathrm{MBC}$ and SOC. Metabolic quotient $\left(\mathrm{qCO}_{2}\right)$ negatively correlated with microbial quotient (MBC:SOC), depicting that higher values of $\mathrm{qCO}_{2}$ signify difficulties in using organic substrates during microbial activity as a result of low MBC:SOC. Changes in
\end{abstract}


LUMS affected the mineralization kinetics of SOC in the study area.

\section{Keywords}

Land Use, Carbon Mineralization, Kinetic Models, Mount Bambouto Caldera

\section{Introduction}

Land use and management patterns are inherently associated with changes in soil nutrients and soil quality parameters, which affect the immediate biophysical environment and agricultural productivity. From a microbiological perspective, soil organic carbon (SOC) mineralization is an indicator of soil health [1] [2] and is related to long term soil fertility. Steady population growth increasingly triggers the conversion of natural vegetation to different land use types and management patterns [3] [4] with significant changes in soil properties and associated soil health implications. The effects of land use changes on soil carbon pools and atmospheric $\mathrm{CO}_{2}$ concentrations have various environmental implications [3] [5] [6] since soils serve as $C$ sinks and are large sources of atmospheric carbon supply. Due to increasing large carbon losses from land use changes over the years [3] [7], efforts to understand the manifestation of biological activities of soils in different land use types and management are being intensified. There is need to be abreast with variations that occur in the organic carbon pool due to land use changes since they have implications on the sustainable management of ecosystems [8] [9].

Soil respiration is undoubtedly one of the fundamental processes in the carbon cycle that represents the pathway by which carbon is returned to the atmosphere [5]. Several studies have used measurements of microbial respiration to estimate carbon mineralization rates [10]. The process involves the emission of $\mathrm{CO}_{2}$ during organic matter decomposition, which is carried out by metabolic activity of plant roots and soil microorganisms [11]. This implies that even small changes in soil respiration can affect atmospheric carbon concentrations [12]. In recent times, studies on soil respiration have received considerable attention because of the release of significant quantities of $\mathrm{CO}_{2}$ from the soil to the atmosphere [5]. Hence, assessing the impact of land use changes on soil respiration is of significant importance to provide insight into the relationship between soil metabolism and carbon budgets [13].

Description of the dynamics of C-mineralization in incubation studies by fitting experimental data to kinetic models is important to foster prediction of the ability of soils to supply potentially mineralizable organic carbon [14]. Laboratory incubation under standardized conditions is an effective method to examine C-mineralization [15]. Although a study [16] found a zero-order equation adequately describing C-mineralization, the first order equation has been frequently used to describe the C-mineralization process of SOC [17] [18]. Besides the sim- 
ple first-order model, a two-part parabolic equation is applied [19] that assumes SOC to be divided into a labile fraction and a more recalcitrant one, each decaying exponentially at rates characterized by its own constants ( $k$ and $h$, respectively). Numerous field and laboratory incubation studies have been carried out [13] [20] [21], with most of the studies on the effects of land use changes on soil respiration focused on temperate environments [3] [14] [22]. Soil microbial organisms and activities are greatly affected by site characteristics including soil type, texture, temperature, moisture and $\mathrm{pH}$. Such activities vary with vegetation cover changes and management practices, environmental conditions and land use types [23].

SOC dynamics in different land uses and its contribution to $\mathrm{CO}_{2}$ fluxes continue to pull the attention of researchers as they seek to fill the knowledge dearth between $\mathrm{CO}_{2}$ emissions from soils and LUMS [6]. Quantifying soil microbial activity parameters commonly affected by land use would enhance the evaluation of changes in soil microbial functions that are driven by changes in land use [24]. Hence, this work aimed at: 1) assessing the C-mineralization potentials of soils from different LUMS (grasslands, croplands, natural forest/fallow lands, cocoa/palm plantations, settlement/agro-forests) by laboratory scale incubation experiments; 2) comparing the suitability of different decay models for describing rates and amounts of $\mathrm{C}$-mineralization; 3) evaluating soil microbial activity parameters vis-à-vis the $\mathrm{C}$-mineralization parameters derived from the best fit model.

\section{Materials and Methods}

\subsection{Study Site}

This work was done in Mount Bambouto Caldera Area (Wabane Subdivision) in the South West Region of Cameroon. Situated between latitudes $5^{\circ} 44^{\prime} \mathrm{N}$ and $5^{\circ} 36^{\prime} \mathrm{N}$ and longitudes $9^{\circ} 55^{\prime} \mathrm{E}$ and $10^{\circ} 07^{\prime} \mathrm{E}$, and extending from $200 \mathrm{~m}$ to $2700 \mathrm{~m}$ a.s.l., the topography of the area is highly diverse (Figure 1). Annual rainfall ranges between 2000 - $3000 \mathrm{~mm}$ and mean monthly maximum and minimum temperatures are $32^{\circ} \mathrm{C}$ and $17^{\circ} \mathrm{C}$, respectively [25] [26]. The area has a moist agro-climate with two seasons: rainy season that spans from March to October, and dry season from November to February. It is characterized by a multi-agricultural production system within the caldera and its environs that is water-fed by springs and streams flowing from the caldera top to form rivers in the middle and low lying zones.

The soils in this area are of volcanic origin [27] and range from rich loose alluvial and silty-loam soils, rarely interspersed with outcrops of chalk and clay in the upper belt through sandy-loam to reddish alluvial soils in the middle and lower belts [28]. The undulating mountainous topography at the top is characterized by organic matter-rich andosols between 2000 and $2740 \mathrm{~m}$ altitude [29] [30]. Different soils also found in this upper area are ferralitic red soil on granite, ancient basalt and trachyte, grey and black andosolic soil on recent volcanic 
rocks (basalt, trachyte and pyroclastic) with thicknesses varying between $0.01 \mathrm{~m}$ to $0.60 \mathrm{~m} \mathrm{[31].}$

\subsection{Dominant Land Use and Management Systems}

A survey of the LUMS carried out in 2018 identified five types: grassland, cropland, natural forest/fallow lands, cocoa/palm plantations, and settlements/agro-forests (Table 1). The identification and classification of the five land use and management systems was achieved through interpretation of satellite images and

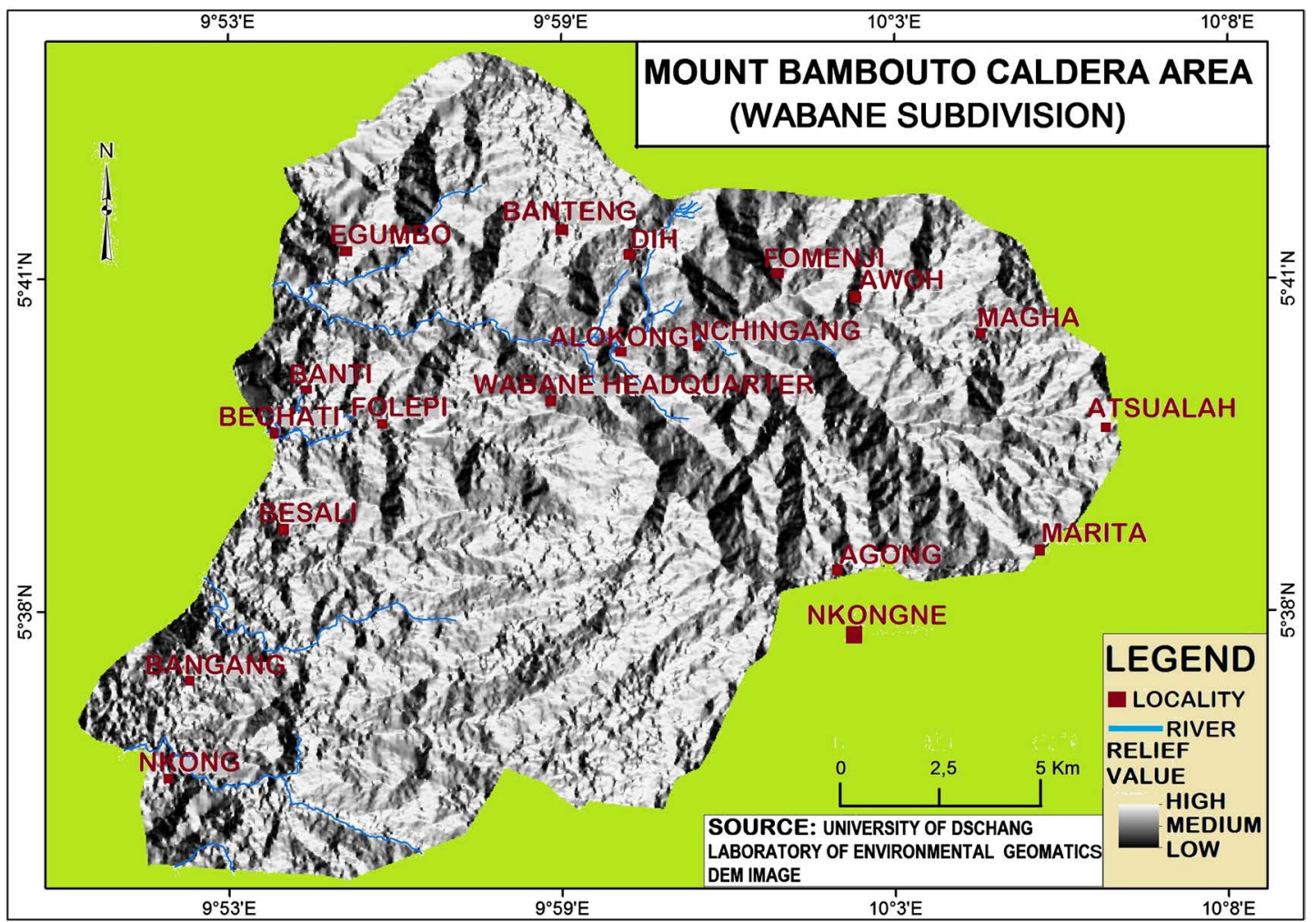

Figure 1. Location of the study site.

Table 1. Land use and management systems (LUMS) in Mount Bambouto Caldera Area of Cameroon.

\begin{tabular}{|c|c|}
\hline $\begin{array}{l}\text { Land use and management } \\
\text { system }\end{array}$ & Description \\
\hline Savannah/Grassland & Extensive open grazing areas dominated by natural tropical grasses \\
\hline Cropland & $\begin{array}{l}\text { Areas or patches of land dominated by monocultures and/or mixed } \\
\text { cropping for cash and subsistence needs }\end{array}$ \\
\hline Natural Forest/Fallow lands & $\begin{array}{l}\text { Primary forest stands or patches of fallow lands that have not been } \\
\text { cropped for at least } 24 \text { months }\end{array}$ \\
\hline Cocoa/Palm Plantations & $\begin{array}{l}\text { Separate cocoa and palm plantations or mixed cocoa/palm planta- } \\
\text { tions interspersed with fruit trees and sometimes food crops }\end{array}$ \\
\hline Settlement/Agro-forests & $\begin{array}{l}\text { Eucalyptus, cypress, pine and/or fruit trees grown around homes } \\
\text { and/or in farms }\end{array}$ \\
\hline
\end{tabular}

Source: (Toh et al., 2018). 
numerous survey trips in the study area [4]. Information about management practices was obtained from land owners, focus groups, key informants and government development agents.

\subsection{Soil Sampling, Preparation and Properties}

Sixteen sites were sampled within each land use system at two depths: $0-20 \mathrm{~cm}$ and $20-40 \mathrm{~cm}$ using a stainless steel soil auger. The sixteen sampled sites were replications while the LUMS were treatments. One hundred and sixty soil samples were collected from the five LU systems at two depths (16 samples per LUMS per depth for 5 LUMS) in a complete randomized block design. The samples were air dried, crushed and sieved through a $2 \mathrm{~mm}$ mesh before laboratory analysis and experiments.

Soil texture analysis was performed using hydrometric methods [32]. Soil $\mathrm{pH}$ was determined by potentiometric methods at a 1:2.5 soil to water ratio suspension while soil organic carbon (SOC) was measured by Walkley and Black method [33]. Total nitrogen (TN) was analysed by wet oxidation procedure of the Kjeldhal digestion, distillation and titration method [34]. Available phosphorus (avP) was determined using Olsen's extraction method [35] while exchangeable bases $\left(\mathrm{Na}^{+}, \mathrm{K}^{+}, \mathrm{Ca}^{2+}\right.$, and $\left.\mathrm{Mg}^{2+}\right)$ were measured by atomic absorption spectrophotometry after extraction by ammonium acetate [36]. The cation exchange capacity (CEC) was determined by extraction with ammonium acetate [37]. Exchangeable-titratable acidity was determined in $1 \mathrm{M} \mathrm{KCL}$ extracts titrated with $0.01 \mathrm{M} \mathrm{NaOH}$.

\subsection{Microbiological Analyses}

Microbiological analyses were carried out in each LU system by measuring microbial activity in the associated soil samples. In the experiments, $40 \mathrm{~g}$ of dried soil sample replicates from each LUMS were wetted to $60 \%$ of water holding capacity and incubated in 0.51 air-tight jars at $27^{\circ} \mathrm{C}$. Carbon dioxide emission was measured by a standard method [38] every 10 days for 10 weeks using a $\mathrm{CO}_{2}$ trap. The trap was prepared using $20 \mathrm{ml}$ of $1.0 \mathrm{M} \mathrm{NaOH}$ and $25 \mathrm{ml}$ of distilled water in a vial for trapping the $\mathrm{CO}_{2}$ evolved. The trap solution in a beaker was placed in the air-tight jar. The control experiment consisted of 0.51 air-tight jars without soil but containing the same alkali as in the other experiments. To determine the quantity of alkali that had not reacted with $\mathrm{CO}_{2}$ at the end of each 10-day period, the trap solution was removed and titrated with $0.1 \mathrm{M} \mathrm{HCl}$ solution using phenolphthalein indicator and $\mathrm{BaCl}_{2}$ solutions. Excess $\mathrm{BaCl}_{2}$ was added to the $\mathrm{NaOH}$ solution to precipitate the carbonate as insoluble $\mathrm{BaCO}_{3}$. The volume of acid needed for the titration was noted and the acid added slowly to avoid contact and dissolution of precipitated $\mathrm{BaCO}_{3}$. The amount of $\mathrm{CO}_{2}$ evolved from the soil during exposure to the alkali was calculated using the formula:

$$
\operatorname{mg~} \mathrm{CO}_{2}=\left(V_{a c}-V_{a s}\right) N E \text {, }
$$


where

$V_{a c}=$ Volume $(\mathrm{ml})$ of acid used to titrate $\mathrm{NaOH}$ in jars from the control experiment,

$V_{\text {as }}=$ Volume (ml) of acid used to titrate the $\mathrm{NaOH}$ in beakers exposed to soil,

$N=$ Normality of the acid,

$E=$ Equivalent weight for $\mathrm{CO}_{2}=22$, and $\mathrm{CO}_{2}$ emission was expressed as $\mathrm{mg}$ $\mathrm{CO}_{2} \mathrm{~kg}^{-1}$ soil.

Soil microbial biomass carbon (MBC) and microbial biomass nitrogen (MBN) were determined by the chloroform fumigation extraction method, using $0.5 \mathrm{M}$ $\mathrm{K}_{2} \mathrm{SO}_{4}$ as extractant [39]. Twenty-five grams of dry weight-equivalent soil samples was fumigated with $\mathrm{CHCl}_{3}$ for 24 hours in a dark room in vacuum desiccators in two duplicates. After removal of chloroform by three repeated evacuations, the soil samples were extracted by $0.5 \mathrm{M} \mathrm{K}_{2} \mathrm{SO}_{4}$ (using a soil: extractant ratio of 1: 4). Similarly, the non-fumigated controls were also subjected to $0.5 \mathrm{M}$ $\mathrm{K}_{2} \mathrm{SO}_{4}$ extraction. After shaking for 30 minutes in automatic shaker, the extract was filtered through whatman filter paper (No. 42). The filtrates were analysed for organic carbon and total nitrogen by using SKALAR TOC/TN automatic analyser. The difference in the carbon content of the extracts from fumigated and non-fumigated samples was converted to biomass carbon by dividing the value obtained by a factor $\left(K_{C}\right)$ of 0.45 [39]. The results were expressed as $\mu \mathrm{g} \cdot \mathrm{g}^{-1}$ of oven dried soil. The difference in content of nitrogen of the extractants was also converted to biomass nitrogen by dividing the value obtained by a factor $\left(K_{N}\right)$ of 0.54 [40]. Metabolic quotient, $\mathrm{qCO}_{2}\left[\left(\mathrm{CO}_{2}-\mathrm{C}\right) \cdot \mathrm{h}^{-1} \cdot \mathrm{g}^{-1} \mathrm{MBC}\right]$, was calculated from respiratory data using the formula [41]:

$$
\mathrm{qCO}_{2}=\left[\left(\mathrm{CO}_{2}-\mathrm{C}\right) \text { mineralized } / \mathrm{MBC}\right]
$$

Metabolic quotient was considered an index of microbial efficiency in utilizing the available resources, with low efficiency attributed to high values of $\mathrm{qCO}_{2}$ and vice versa.

\subsection{Models Used for Carbon Mineralization Studies}

To detect anomalies, descriptive and graphical analyses of $\mathrm{CO}_{2}$ respiration data were done for data obtained during the ten-week incubation period of soil samples from different LUMS and depths. Different models were used to describe the $\mathrm{CO}_{2}$ respiration. The models were tested to determine the one that best suited the data. Then, the convergence, values of adjusted coefficient of determination $\left(R_{a d j .}^{2}\right)$, squared sum error (SSE) and mean square error (MSE) were employed to select the best-fit model for the data. The model fittings were done by applying MODEL procedures of the SAS/STAT ${ }^{\circledR}$ statistical programme [42]. Table 2 presents five kinetic models used to describe the soil carbon mineralization.

\subsection{Relation between Biochemical Parameters and Organic Carbon}

When the model was fitted, different parameters were determined to analyse the potentially mineralizable carbon $\left(C_{o}\right)$, rate constant of carbon mineralization $(k)$, 
Table 2. Models employed in describing soil carbon mineralization kinetics in the Mount Bambouto Caldera Area.

\begin{tabular}{ccc}
\hline No. & MODEL & EQUATION \\
\hline 1. & Zero order & $C_{t}=a+k t \quad[16]$ \\
2. & Linearized power function & $C_{t}=k t^{m}$ \\
3. & First order & $C_{t}=C_{o}\left(1-\mathrm{e}^{-k t}\right)$ \\
4. & Two simultaneous reactions & $C_{t}=C_{1}\left(1-\mathrm{e}^{-k t}\right)+C_{2}\left(1-\mathrm{e}^{-h t}\right)$ \\
5. & Special model & $C_{t}=C_{1}\left(1-\mathrm{e}^{-k t}\right)+h t$
\end{tabular}

Note: $C_{b} C_{o}, C_{1}$ and $C_{2}=$ Cumulative carbon mineralized after time $t$, potentially mineralizable, easily mineralizabe, and slowly mineralizable carbon $\left(\mathrm{mgC}-\mathrm{CO}_{2} / \mathrm{kg}\right.$ soil), respectively; $a=$ intercept; $k, m$ and $h=$ rate constants $\left(\right.$ day $\left.^{-1}\right)$; $t=$ time from the start of incubation.

initial potential rate of carbon mineralization $\left(C_{o}^{*} k\right)$, and half-life of carbon $\left(t_{1 / 2}\right)$. A mixed model was applied to detect significant differences in the measured variables as a function of LUMS at the two depths. The depth was regarded as a repeated measure factor while the statistical model was expressed thus:

$$
Y_{i j ; k}=\mu+\alpha_{i}+\beta_{j}+\gamma_{k}+\beta \gamma_{j k}+\mathcal{E}_{i j ; k}
$$

with $i=1, \cdots, 16$ for sites, $j=1, \cdots, 5$ for LUMS and $k=1,2$ for the two depths;

$Y_{i j k k}=$ observed value of the dependent variable for LUMS $j$ at depth $k$ in site $i$.

$\mu$ = general mean effect; $\alpha_{i}=$ mean effect of the site $i ; \beta_{j}=$ mean effect of the LUMS $;$

$\gamma_{k}=$ mean effect of the depth $k, \beta \gamma_{j k}=$ interaction effect of the land use $j$ with the depth $k$,

$\mathcal{E}_{i j ; k}=$ random error in the dependent variable for the LUMS $j$ at depth $k$ in the site $i$.

Assumptions for the model were that: $\mathcal{E}_{i j ; k} \sim N\left(0, \sigma_{k}^{2}\right)$, with $\sigma_{k}^{2}=$ random variance for errors at depth $k$, and

$$
\operatorname{Cov}\left(\mathcal{E}_{i j ; k}, \mathcal{E}_{i j^{\prime} ; k^{\prime}}\right)= \begin{cases}\omega & \text { if } i=i^{\prime}, j=j^{\prime} \text { and } k=k^{\prime} \\ 0 & \text { if } i \neq i^{\prime}, j \neq j^{\prime}\end{cases}
$$

$\omega=$ covariance between errors at different depths.

\section{Results and Discussion}

\subsection{Soil Respiration}

Figure 2 shows the carbon dioxide- $\mathrm{C}$ mineralization changes in soils from the LUMS within 10 weeks of incubation for the $0-20 \mathrm{~cm}$ soil depth. In all LUMS, there was a decline with highest values $\left(485,260,275,250\right.$, and $\left.270 \mathrm{mgkg}^{-1}\right) \mathrm{re}-$ corded in the first 10 days and lowest values $\left(115,105,100,100\right.$, and $\left.105 \mathrm{mgkg}^{-1}\right)$ obtained in the last 10 days of experimentation for grassland (savannah), cropland, palm/cocoa, settlement/agroforest, and fallow/forest respectively.

The carbon dioxide-C mineralization rates for the 70 days incubation followed 
a similar pattern in all five LUMS wherein an initial high value at the start decreased with time and almost equilibrated to an averagely constant value in the last days of incubation. Figure 3 shows carbon dioxide-C mineralization changes in soils from the LUMS at $20-40 \mathrm{~cm}$ depth for the same incubation period.

A general trend of decline is still observed with the first 30 days being rapid and the last 40 days gentler. Again, grasslands portray higher values and rates than the rest of the LUMS. The $\mathrm{CO}_{2}$ emission in both $0-20 \mathrm{~cm}$ and $20-40 \mathrm{~cm}$ soil profiles was higher in grassland than other LUMS. The faster release of $\mathrm{CO}_{2}$ in the early days of incubation implies a rapid depletion of an easily mineralizable carbon fraction, leaving a more resistant fraction of SOC [46] [47] [48]. Carbon mineralization is influenced by different cropping systems [49] or LUMS. Higher $\mathrm{CO}_{2}$ release in grassland samples could be ascribed to high organic matter content, in agreement with [50] who reported higher $\mathrm{CO}_{2}$ emissions under grassland than afforested land. Higher microbial respiration rates

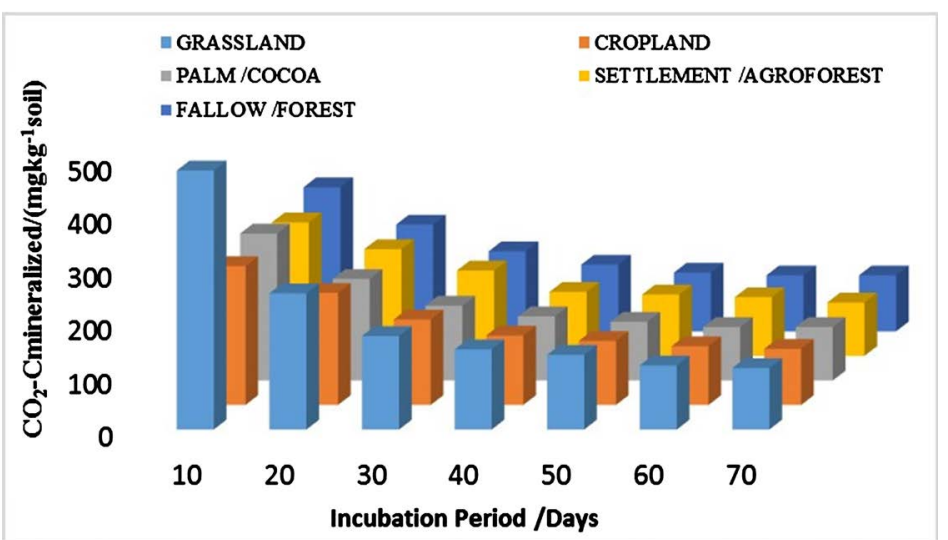

Figure 2. Carbon mineralization rates $(0-20 \mathrm{~cm})$ for land use and management systems (LUMS) in Mount Bambouto Caldera Area during 70 days of laboratory incubation $(n=$ $10)$.

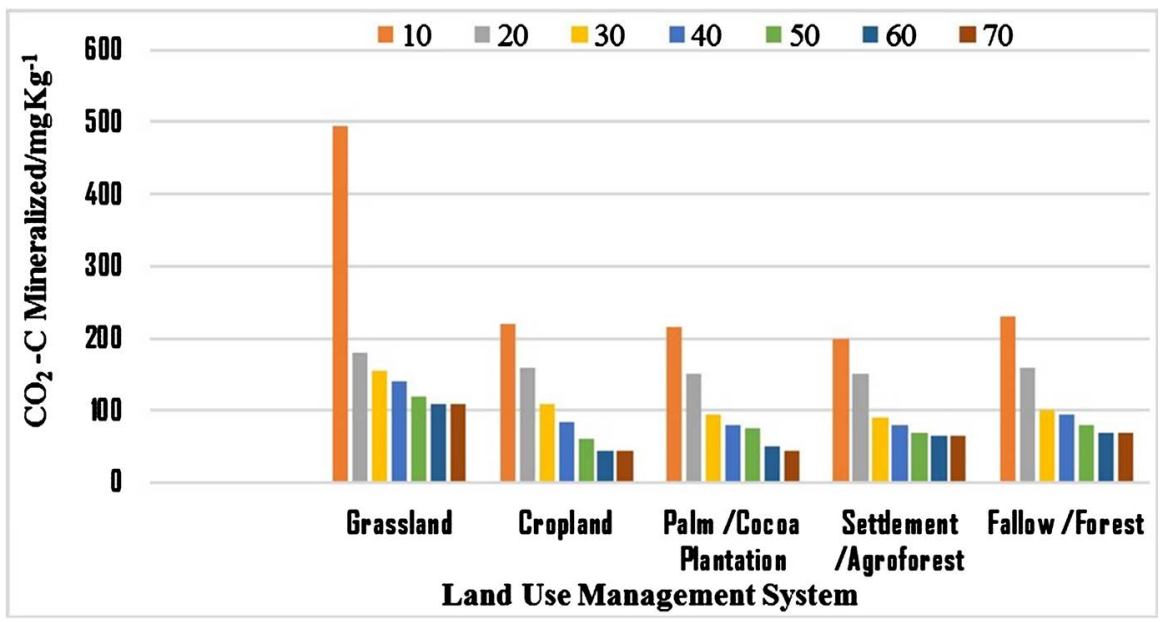

Figure 3. Changes in soil carbon dioxide-C mineralization from land use and management systems (LUMS) in Mount Bambouto Caldera Area $(20-40 \mathrm{~cm})$. 
had also been reported in grasslands than other land uses [51] [52]. High rates of soil respiration can be attributed to a large pool of labile carbon substrates or rapid oxidation of a smaller pool [53] [52] [49]. Hence, a high basal respiration may be a pointer to ecological stress and degradation or high level of ecosystem productivity. The low $\mathrm{CO}_{2}$ emissions under palm/cocoa plantations and settlement/agroforests could be attributed to low rate of microbial activity. High SOC and $\mathrm{MBC}$ result in high soil respiration [23] [54], which means the high mineralizable carbon in grasslands indicates a more easily decomposable organic matter while the low mineralizable carbon in other LUMS signifies a more difficult to decompose organic matter.

\subsection{Kinetics of the Carbon Mineralization}

Table 3 shows results of the microbial mineralization activity of soils from LUMS at two depths in Mount Bambouto Caldera Area estimated using the first order equation. In consideration of convergence, statistical parameters of fitting, and significance of estimated values, the first order model, $\left[C_{t}=C_{o}\left(1-\mathrm{e}^{-k t}\right)\right]$, was selected for the experimental data because it presented a good fit to C-mineralization with a coefficient of determination, $R^{2}$, between 0.83 and 0.99 for all the LUMS.

The highest mean value of potentially mineralizable carbon $\left(C_{o}\right)(1477.4$ $\mathrm{mgCO}_{2}-\mathrm{C} / \mathrm{kg}$ soil) was observed in grassland in the surface layer $(0-20 \mathrm{~cm})$ while the lowest mean value $\left(543.5 \mathrm{mgCO}_{2}-\mathrm{C} / \mathrm{kg}\right.$ soil) was recorded in croplands in the $20-40 \mathrm{~cm}$ soil profile. The soils of grasslands in $0-20 \mathrm{~cm}$ profile showed a significantly higher rate constant $(k)$ for $\mathrm{C}$ mineralization, which was not statistically different from soils of settlement/agro-forest within the same depth.

Table 3. Microbial mineralization activity of soils from LUMS at two depths in Mount Bambouto Caldera Area, estimated using first order equation.

\begin{tabular}{|c|c|c|c|c|c|}
\hline Depth & $L U M S$ & $\begin{array}{c}C_{o} \\
\left(\mathrm{mgCO}_{2}-\mathrm{C} / \mathrm{kg} \text { soil }\right)\end{array}$ & $k\left(\right.$ day $\left.^{-1}\right)$ & $t_{1 / 2}$ (day) & $\begin{array}{c}\mathrm{qCO}_{2} \\
{\left[\left(\mathrm{mgCO}_{2}-\mathrm{Ch}^{-1}\right) / \mathrm{g} \mathrm{MBC}\right]}\end{array}$ \\
\hline \multirow[t]{5}{*}{$0-20 \mathrm{~cm}$} & Grassland & $1477.4 \pm 1.7 \mathrm{Aa}$ & $0.04310 \pm 0.0004 \mathrm{Aa}$ & $21.6 \pm 1.1 \mathrm{Ca}$ & $1.163 \pm 0.02 \mathrm{Ba}$ \\
\hline & Cropland & $1429.5 \pm 1.3 \mathrm{ABa}$ & $0.02367 \pm 0.0002 \mathrm{Ca}$ & $26.8 \pm 1.3 \mathrm{Ba}$ & $1.135 \pm 0.04 \mathrm{BCa}$ \\
\hline & Palm/Cocoa Plantation & $613.0 \pm 0.8 \mathrm{Ca}$ & $0.04031 \pm 0.0003 \mathrm{ABa}$ & $25.1 \pm 1.4 \mathrm{BCa}$ & $0.840 \pm 0.01 \mathrm{Ca}$ \\
\hline & Settlement/Agro-forest & $834.7 \pm 0.9 \mathrm{BCa}$ & $0.04201 \pm 0.0001 \mathrm{Aa}$ & $24.3 \pm 1.2 \mathrm{BCa}$ & $1.235 \pm 0.02 \mathrm{ABa}$ \\
\hline & Fallow/forest land & $1018.5 \pm 1.1 \mathrm{Ba}$ & $0.03012 \pm 0.0002 \mathrm{Ba}$ & $34.7 \pm 1.3 \mathrm{Aa}$ & $1.848 \pm 0.03 \mathrm{Aa}$ \\
\hline \multirow[t]{5}{*}{$20-40 \mathrm{~cm}$} & Grassland & $1415.5 \pm 1.2 \mathrm{Aa}$ & $0.04142 \pm 0.0003 \mathrm{Aa}$ & $24.6 \pm 0.9 \mathrm{Cb}$ & $1.253 \pm 0.01 \mathrm{BCa}$ \\
\hline & Cropland & $543.5 \pm 0.7 \mathrm{Cb}$ & $0.03813 \pm 0.0002 \mathrm{ABb}$ & $27.8 \pm 0.7 \mathrm{BCa}$ & $1.121 \pm 0.05 \mathrm{Ca}$ \\
\hline & Palm/Cocoa Plantation & $772.0 \pm 0.9 \mathrm{BCb}$ & $0.03779 \pm 0.0003 \mathrm{ABb}$ & $27.1 \pm 0.6 \mathrm{BCb}$ & $2.018 \pm 0.02 \mathrm{ABb}$ \\
\hline & Settlement/Agroforest & $795.7 \pm 0.8 \mathrm{BCa}$ & $0.03501 \pm 0.0004 \mathrm{Bb}$ & $30.3 \pm 1.2 \mathrm{Bb}$ & $1.703 \pm 0.01 \mathrm{Bb}$ \\
\hline & Fallow /Forest land & $1043.5 \pm 1.2 \mathrm{ABa}$ & $0.02505 \pm 0.0005 \mathrm{Cb}$ & $53.1 \pm 1.4 \mathrm{Ab}$ & $2.720 \pm 0.02 \mathrm{Ab}$ \\
\hline
\end{tabular}

Note: Different upper case letters (A, B, C, AB, BC) show significant differences at each depth between different LUMS; different lower case letters (a, b) show significant differences in each LUMS between the two depths. LUMS: land use and management system, $C_{i}$ : potentially mineralizable carbon, $k$ : rate constant of carbon mineralization, $t_{1 / 2}$ : half-life, $\mathrm{qCO}_{2}$ : metabolic quotient. 
Cropland and fallow/forest land had $k$ values which were significantly lower than other LUMS in $0-20 \mathrm{~cm}$ soil profile. The half-life $\left(t_{1 / 2}\right)$ in fallow/forest lands was significantly higher than those of other LUMS at both levels while the lowest value of $t_{1 / 2}$ was recorded in grassland irrespective of soil depth.

The use of the first order kinetic model to describe C-mineralization of soil organic matter presupposes that microbial biomass is constant and the rate of decomposition depends on available substrate. Other studies [18] [17] [10] [55] [6] have also fitted C-mineralization data with the first order model. Generally, decreases in potentially mineralizable carbon $\left(C_{o}\right)$ are either associated with a low microbial activity or residues that are more difficult to decompose. Therefore, the high values of $C_{o}$ observed in grassland at the $0-20 \mathrm{~cm}$ depth suggest residues that are easier to decompose or associated with high microbial activity. Microbial biomass carbon (MBC) is the living or active pool in models that simulate organic carbon turnover in soils. The size of $\mathrm{MBC}$ directly affects the model output [56] [57]. Hence, differences in SOC and MBC in LUMS could be important contributors to differences observed in the outputs of carbon kinetic models. High half-life values are generally associated with ecosystem stress [58]. Consequently, the higher value of half-life observed in fallow/forest lands insinuates low carbon mineralization rate and greater stress of the ecosystem.

The mean values of $\mathrm{qCO}_{2}$ in fallow/forest land were higher than other LUMS at both levels. The highest value of $\mathrm{qCO}_{2}$ was recorded in fallow/forest land at the $20-40 \mathrm{~cm}$. Carbon kinetics parameters were significantly influenced by depth of sampling. In $0-20 \mathrm{~cm}$, mean values of $\mathrm{qCO}_{2}$ recorded in palm/cocoa plantation and fallow/forest land were significantly lower than the values in 20 $40 \mathrm{~cm}$ respectively.

High MBC and soil respiration generally indicate better soil quality [59] but do not always show the same trend. Therefore, metabolic quotient $\left(\mathrm{qCO}_{2}\right)$ is employed to evaluate efficiency of soil microbial biomass in utilizing organic carbon [60]. High values of $\mathrm{qCO}_{2}$ are interpreted as a high requirement of maintenance energy or lower metabolic efficiency. Ecologically, high $\mathrm{qCO}_{2}$ reflects high maintenance carbon demand [58] while low $\mathrm{qCO}_{2}$ suggests more stable ecosystems. These findings corroborate other results [61].

\subsection{Soil Organic Carbon, Microbial Biomass Carbon, Total Mineralized Carbon and Initial Potential Rate of Carbon Mineralization}

Table 4 summarizes SOC, MBC, $C_{t}$ and $C_{o}^{*} k$ as impacted by LUMS and soil depth in Mount Bambouto Caldera Area.

Grassland soils had significantly $(\mathrm{p}<0.001)$ higher SOC and MBC than other LUMS except settlement/agro-forest where SOC did not differ. Mean values of SOC between cropland and palm/cocoa plantations did not show any significant statistical difference. The carbon mineralized during the 70 days of incubation in grassland was significantly higher than in other LUMS. The $C_{t}$ observed in fallow/forest lands was significantly lower than other LUMS. Also, mean values of 
Table 4. SOC, MBC, $C_{t}$ and $C_{o}^{\star} k$ impacted by land use and management systems and soil depth, with standard error and P-values of ANOVA.

\begin{tabular}{|c|c|c|c|c|}
\hline LUMS & $\begin{array}{c}\text { SOC } \\
\text { [g/kg soil] }\end{array}$ & $\begin{array}{c}\text { MBC } \\
{[\mathrm{mg} / \mathrm{kg} \text { soil }]}\end{array}$ & $\begin{array}{c}C_{t} \\
{\left[\mathrm{mg} \mathrm{CO}_{2}-\mathrm{C} / \mathrm{kg}\right.} \\
\text { soil }]\end{array}$ & $\begin{array}{c}C_{o}{ }^{*} k \\
{\left[\mathrm{mg} \mathrm{CO}{ }_{2}-\mathrm{C} / \mathrm{kg}\right.} \\
\text { soil day] }\end{array}$ \\
\hline Grassland & $5.0 \pm 0.6 \mathrm{a}$ & $794.8 \pm 1.9 \mathrm{a}$ & $639.3 \pm 1.1 \mathrm{a}$ & $47.1 \pm 0.7 \mathrm{a}$ \\
\hline Cropland & $4.0 \pm 0.3 \mathrm{ab}$ & $487.6 \pm 0.9 b$ & $346.8 \pm 0.8 \mathrm{bc}$ & $22.2 \pm 0.3 \mathrm{bc}$ \\
\hline Palm/Cocoa Plantation & $4.0 \pm 0.2 \mathrm{ab}$ & $668.9 \pm 1.2 \mathrm{ab}$ & $509.5 \pm 0.4 \mathrm{ab}$ & $37.1 \pm 0.5 \mathrm{ab}$ \\
\hline Settlement/Agroforest & $5.0 \pm 0.1 \mathrm{a}$ & $493.6 \pm 0.8 b$ & $445.9 \pm 0.2 b$ & $30.3 \pm 0.2 b$ \\
\hline Fallow/Forest Land & $3.0 \pm 0.3 b$ & $198.6 \pm 0.5 c$ & $159.7 \pm 0.1 \mathrm{c}$ & $14.8 \pm 0.1 \mathrm{c}$ \\
\hline S.e & 0.1 & 45.66 & 24.90 & 24.90 \\
\hline \multicolumn{5}{|l|}{ DEPTH (D) } \\
\hline $0-20 \mathrm{~cm}$ & $4.2 \pm 0.8$ & $527 \pm 1.3 \mathrm{a}$ & $226.1 \pm 1.2 \mathrm{a}$ & $26.9 \pm 0.4 \mathrm{a}$ \\
\hline $20-40 \mathrm{~cm}$ & $4.3 \pm 0.6$ & $434 \pm 1.1 b$ & $421.9 \pm 1.6 b$ & $30.2 \pm 0.5 b$ \\
\hline S.e & 0.1 & 14.57 & 9.92 & 0.82 \\
\hline \multicolumn{5}{|l|}{ ANOVA } \\
\hline LUMS & $* * *$ & $* * *$ & $* * *$ & $* * *$ \\
\hline Depth (D) & ns & $* * *$ & $* * *$ & * \\
\hline LUMS $\times$ D & ns & ns & ns & ns \\
\hline
\end{tabular}

Note: LUMS: land use and management system, SOC: soil organic carbon, MBC: microbial biomass carbon, $C_{i}$ : total carbon mineralized in 70 days, $C_{o}^{*} k$. initial potential rate of $\mathrm{C}$ mineralization, S.e: standard error, ${ }^{\dagger}$ Mean values with similar letters ( $\mathrm{a}, \mathrm{b}, \mathrm{c}, \mathrm{ab}, \mathrm{bc}$ ) in each column indicate non-significant differences at ${ }^{*} \mathrm{p}<$ $0.05,{ }^{* * *} \mathrm{P}<0.001, \mathrm{~ns}=$ not significant

$C_{o}^{*} k$ recorded in grassland were significantly higher than other LUMS and fallow/forest lands presented the lowest value. The values of $C_{t}$ and $C_{o}^{*} k$ were significantly higher in $20-40 \mathrm{~cm}$ than $0-20 \mathrm{~cm}$ depths. Low SOC in forest/fallow lands could be attributed to low carbon inputs through biomass return as well as $\mathrm{C}$ losses through soil erosion. Meta-analyses of land use change experiments [62] [59] showed that the conversion of grassland/savannah to cropland resulted in significant losses of SOC, whereas the conversion of forest to grassland did not cause SOC losses. The increase in carbon content in grasslands suggests that such soils serve as carbon sinks in the ecosystem.

\subsection{Correlation between Soil Variables}

Soil organic carbon (SOC) was used to predict $C_{o}$ in 70 days, which was evaluated using linear regression on eighty observations (Figure 4).

Figure 4(f) summarizes Figures 4(a)-(e), and shows a moderate positive correlation between SOC and $C_{o}$ with a correlation coefficient, $r$, of 0.56 and coefficient of determination, $R^{2}$, of 0.34 representing a potentially mineralizable percentage of $34 \%$ of the SOC. The relationship between $\mathrm{qCO}_{2}$ and MBC:SOC (Figure 5) shows that both soil biological parameters have an inverse relationship; with $\mathrm{qCO}_{2}$ decreasing with increasing MBC:SOC for all LUMS. 

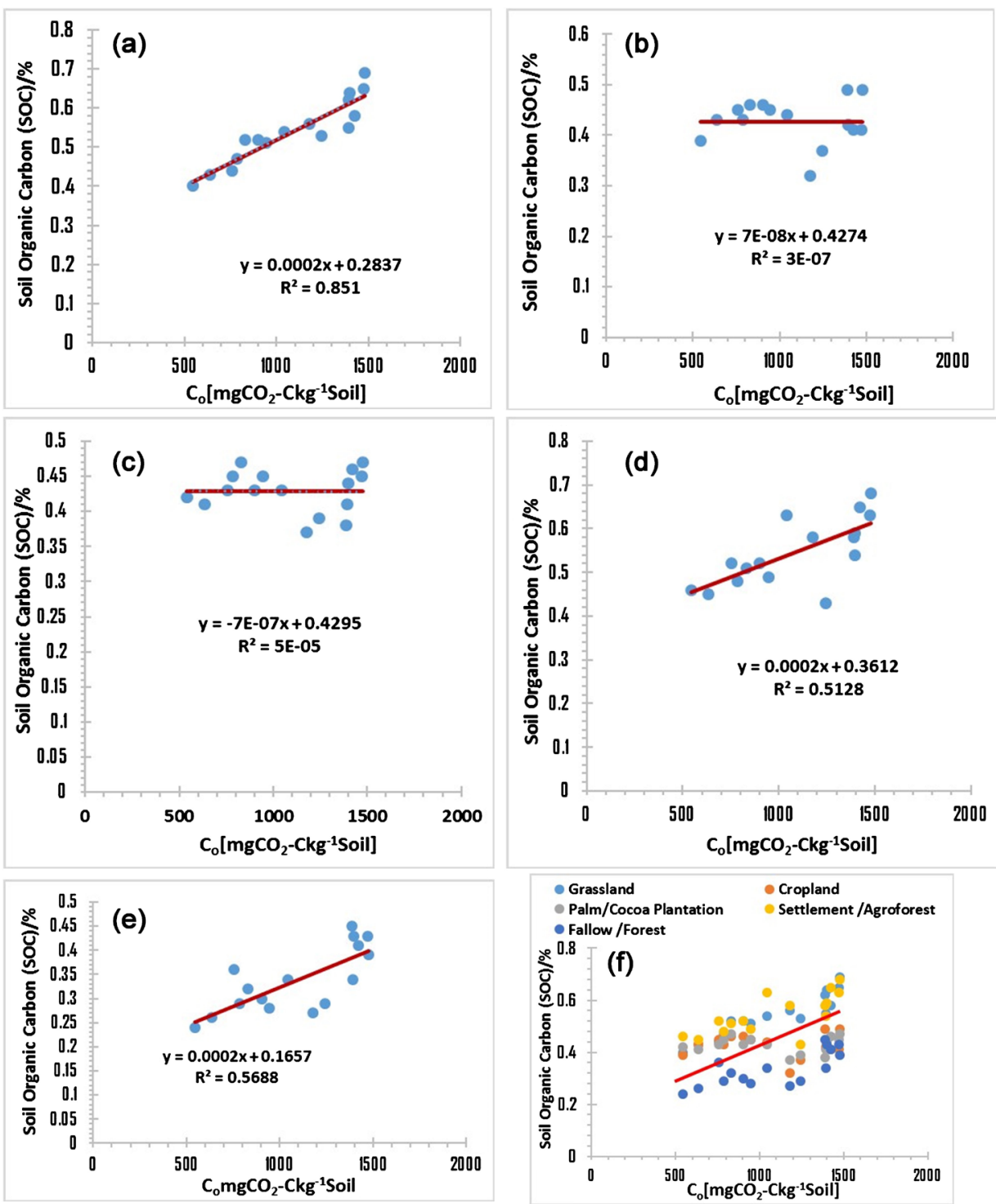

Figure 4. Linear regression between $\mathrm{SOC}$ and $\mathrm{C}_{\mathrm{o}}$ for land use and management systems (LUMS) in Mount Bambouto Caldera Area. (a) Grasslands; (b) Croplands; (c) Palm/Cocoa Plantation; (d) Settlement/Agroforest; (e) Fallow/Forest Lands; (f) All LUMS. $y=324.07 \mathrm{x}+$ $371.49, \mathrm{R}^{2}=0.34, \mathrm{r}=0.56^{* *}, \mathrm{p}<0.01, \mathrm{n}=80$.

Figure 5(f) summarizes (a)-(e), and shows a moderately strong negative correlation between metabolic quotient and MBC:SOC fraction with a correlation coefficient, $r,-0.53$ and coefficient of determination, $R^{2}, 0.28$ representing $28 \%$ of the MBC:SOC fraction. While fallow/forest lands portray the highest $\mathrm{qCO}_{2}$ with lowest MBC:SOC, grassland showed the lowest level $\mathrm{qCO}_{2}$ and highest MBC:SOC. Palm/cocoa plantations followed grassland though $\mathrm{qCO}_{2}$ values for grassland were averagely higher while cropland and settlement/agro-forest were similar with no remarkable differences. Correlation coefficients $(r)$ between some physical, chemical and microbiological parameters (Table 5 ) show a positive correlation between $\mathrm{SOC}$ and $\mathrm{C}$ mineralization parameters $\left(C_{t} C_{o}, k\right.$ and $C_{o}^{*} k$ ) estimated using the first-order mineralization model. 

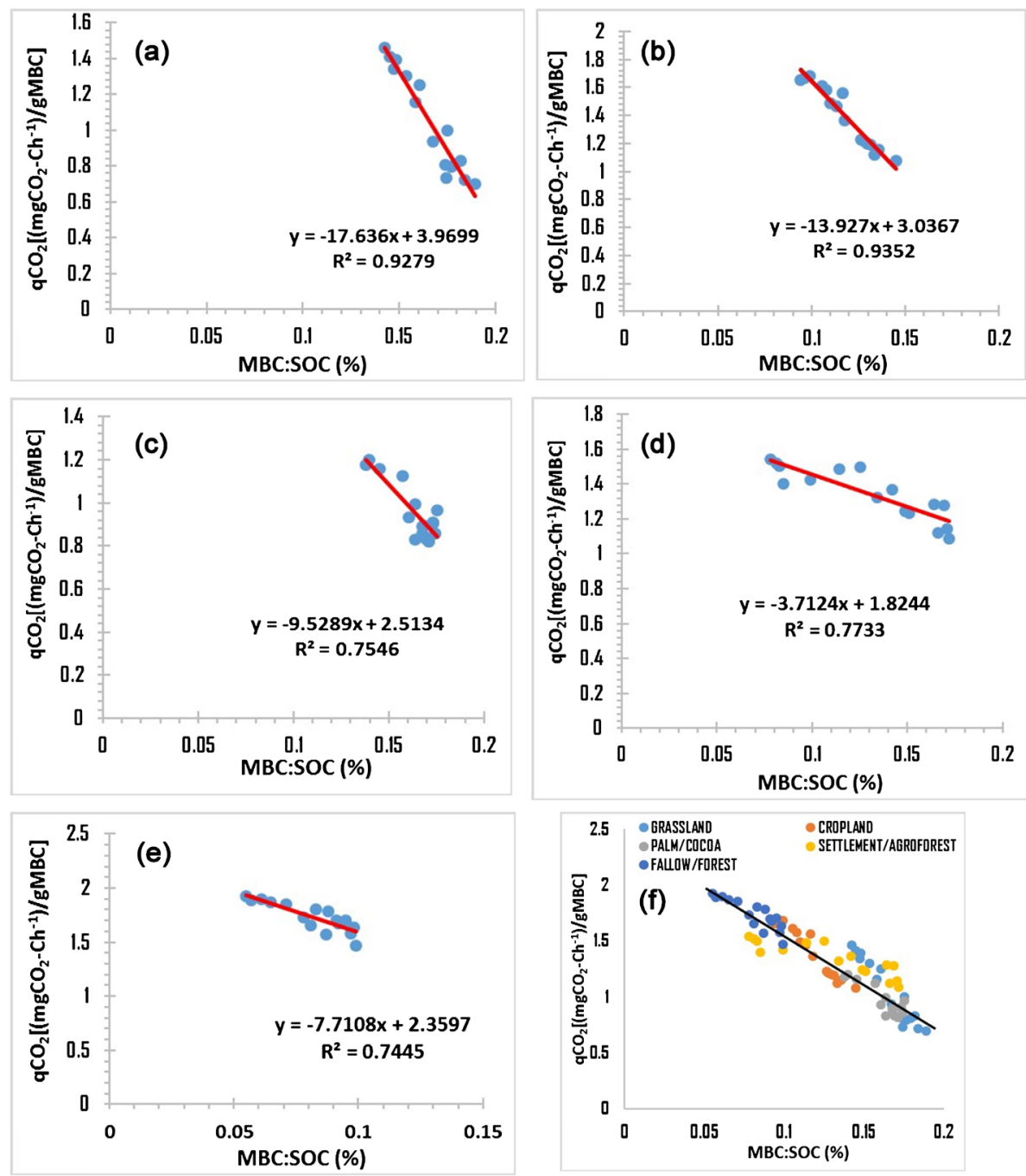

Figure 5. Linear regression between $\mathrm{qCO}_{2}$ and $\mathrm{MBC}$ :SOC for land use and management systems (LUMS) in Mount Bambouto Caldera. (a) Grassland; (b) Cropland; (c) Palm/Cocoa Plantation; (d) Settlement/Agroforest; (e) Fallow/Forest Lands; (f) All LUMS. y $=-432.04 \mathrm{x}$ $+355.49, \mathrm{R}^{2}=0.28, \mathrm{r}=-0.53^{\star *}, \mathrm{P}<0.001, \mathrm{n}=80$.

Table 5. Spearman correlation coefficients between soil characteristics and C-mineralization parameters of the first order model.

\begin{tabular}{|c|c|c|c|c|c|c|}
\hline Parameter & $C_{t}$ & $C_{o}$ & $k$ & $C_{o}{ }^{\star} k$ & $t_{1 / 2}$ & $\mathrm{qCO}_{2}$ \\
\hline Sand & ns & ns & $0.263^{*}$ & ns & $-0.263^{*}$ & ns \\
\hline Clay & $0.273^{*}$ & $0.331^{\star}$ & ns & $0.257^{\star}$ & ns & $0.220^{*}$ \\
\hline $\mathrm{pH}$ & $0.351^{\star *}$ & ns & $0.381^{\star *}$ & $0.368^{* *}$ & $-0.383^{\star \star}$ & $-0.370^{\star *}$ \\
\hline SOC & $0.637^{\star *}$ & $0.434^{\star *}$ & $0.312^{*}$ & $0.615^{*}$ & $-0.312^{*}$ & ns \\
\hline $\mathrm{TN}$ & $0.611^{\star *}$ & $0.415^{\star \star}$ & $0.333^{\star}$ & $0.616^{* *}$ & $-0.340^{*}$ & ns \\
\hline $\mathrm{MBC}$ & $0.631^{\star *}$ & $0.362^{\star \star}$ & $0.324^{\star}$ & $0.595^{\star *}$ & $-0.323^{\star}$ & $-0.656^{* * *}$ \\
\hline $\mathrm{MBN}$ & $0.421^{\star *}$ & $0.270^{*}$ & ns & $0.517^{\star *}$ & ns & $-0.867^{\star * *}$ \\
\hline
\end{tabular}

Note: $C_{t}=$ total carbon mineralized in 70 days, $C_{o}=$ potentially mineralizable $\mathrm{C}, k=\mathrm{C}$ mineralization rate, $C_{o}^{\star} k=$ initial potential rate of $\mathrm{C}$ mineralization, $t_{1 / 2}=$ half-life, $\mathrm{SOC}=$ soil organic carbon, $\mathrm{TN}=$ total nitrogen, $\mathrm{MBC}=$ microbial biomass carbon, $\mathrm{MBN}=$ microbial biomass nitrogen, $\mathrm{ns}=$ not significant, ${ }^{*} \mathrm{p}<0.05$, ${ }^{* *} \mathrm{p}<0.01$ and ${ }^{* * *} \mathrm{p}<0.001$. 
Carbon mineralization parameters also had significant positive associations with MBC even though both SOC and MBC negatively correlated with $t_{1 / 2}$. Good correlation ( $r=0.61,0.42$ and 0.62 ) was also observed between TN and $C_{t}$, TN and $C_{o}$, and TN and $C_{o}^{*} k$ respectively. Correlation between $\mathrm{qCO}_{2}$ and $\mathrm{MBN}$ as well as $\mathrm{qCO}_{2}$ and $\mathrm{MBC}$ was negative and statistically significant $(\mathrm{p}<0.001)$.

Good correlation between $\mathrm{MBC}$ or SOC and $\mathrm{C}$ mineralization parameters intimates that $\mathrm{C}$ mineralization is influenced by the availability of $\mathrm{MBC}$ and SOC for microbial activity. The negative correlation between soil variables with an inverse relationship between $\mathrm{qCO}_{2}$ and microbial quotient (MBC:SOC) depicts that higher values of $\mathrm{qCO}_{2}$ may signify difficulties in using organic substrates during microbial activity as a result of low levels of MBC:SOC. Low MBC:SOC ratio had been reported as an indication of deficiency in available carbon in the soil [63]. MBC:SOC has also been reported as an effective early indicator of the amelioration or deterioration of soil quality [64] [59].

\section{Conclusion}

More $\mathrm{CO}_{2}-\mathrm{C}$ was mineralized in grassland than other LUMS, indicating higher rate of microbial activity and carbon cycling. Land use change from grassland to other LUMS caused a decrease in SOC and MBC. Grasslands enhanced more SOC accumulation and decomposition and were found better carbon sinks than other LUMS. Parameters estimated using the first-order model such as $C_{o}, C_{o}^{\star} k$ and $\mathrm{qCO}_{2}$ were better discriminators among LUMS. Therefore, together with SOC and MBC, they were sensitive to LU changes, and could be taken as indicators of good soil quality. Hence, changes in LUMS affect the mineralization kinetics of SOC and calls for interdisciplinary stakeholders (NGOs, conservationists, researchers, and local officials in charge of agriculture and environmental protection) to engage in awareness campaigns directed at communities, CIGs, and traditional authorities, on the rapid degradation of soils and the resulting negative effects.

\section{Acknowledgements}

We are grateful to all who contributed to the accomplishment of this work; particularly local administrative authorities and chiefs of Wabane Subdivision for administrative clearances and all assistance to reach our targets in the study process. The following chiefs and notables facilitated our stay and movements in the field: Follah of Bangang, Taliteba Elias of Banti, Fomeluh Chrisantus of Dih, Fontalewunta of Bechati and Fongoh Mathias of Magha. We appreciate all of them for accommodating the research teams and all support staff for their assistance in the field.

\section{Funding}

This research did not receive any specific grant from funding agencies in the public, commercial, or not-for-profit sectors. 


\section{Conflicts of Interest}

The authors declare no conflicts of interest regarding the publication of this paper.

\section{References}

[1] Thomsen, M., Faber, J.H. and Sorensen, P.B. (2012) Soil Ecosystem Health and Services-Evaluation of Ecological Indicators Susceptible to Chemical Stressors. Ecological Indicators, 16, 67-75. https://doi.org/10.1016/j.ecolind.2011.05.012

[2] Tian, J., Lu, S., Fan, M., Li, X. and Kuzyakov, Y. (2013) Labile Soil Organic Matter Fractions as Influenced by Non-Flooded Mulching Cultivation and Cropping Season in Rice-Wheat Rotation. Eurasian Journal of Soil Biology, 56, 19-25. https://doi.org/10.1016/j.ejsobi.2013.02.001

[3] Chang, Y., Hou, K., Li, X., Zhang, Y. and Chen, P. (2018) Review of Land Use and Land Cover Change Research Progress. Earth and Environmental Science, 113, Article ID: 012087. https://doi.org/10.1088/1755-1315/113/1/012087

[4] Toh, F.A., Angwafo, T., Ndam, L.M. and Antoine, M.Z. (2018) The Socio-Economic Impact of Land Use and Land Cover Change on the Inhabitants of Mount Bambouto Caldera of the Western Highlands of Cameroon. Advances in Remote Sensing, 7, 25-45. https://doi.org/10.4236/ars.2018.71003

[5] Iqbal, J., Hu, R., Lin, S., Ahamadou, B. and Feng, M. (2009) Carbon Dioxide Emissions from Ultisol under Different Land Uses in Mid-Subtropical China. Geoderma, 152, 63-73. https://doi.org/10.1016/j.geoderma.2009.05.011

[6] Desalegn, T., Herrero, C. and Turrión, M.B. (2019) Soil Carbon Mineralization Kinetics as Influenced by Changes in Land Use and Soil Management in the Central Highlands of Ethiopia. Ethiopian Journal of Agricultural Science, 29, 121-137.

[7] Le Quéré, C., Takahashi, T., Buitenhuis, E.T., Rödenbeck, C. and Sutherland, S.C. (2010) Impact of Climate Change and Variability on the Global Oceanic Sink of $\mathrm{CO}_{2}$. Global Biogeochemical Cycles, 24, 4007. https://doi.org/10.1029/2009GB003599

[8] Zhang, M., Huang, X., Chuai, X., Yang, H., Lai, L. and Tan, J. (2015) Impact of Land Use Type Conversion on Carbon Storage in Terrestrial Ecosystems of China: A Spatial Temporal Perspective. Scientific Reports, 5, Article No. 10233. https://doi.org/10.1038/srep10233

[9] Cai, A., Xu, H., Shao, X., Zhu, P., Zhang, W., Xu, M. and Murphy, D. (2016) Carbon and Nitrogen Mineralization in Relation to Soil Particle Size Fractions after 32 Years of Chemical and Manure Application in a Continuous Maize Cropping System. PLoS ONE, 11, e0152521. https://doi.org/10.1371/journal.pone.0152521

[10] Mohammed, A.M., Naab, J.B., Nartey, E. and Adiku, S.G. (2014) Carbon Mineralization from Plant Residue-Amended Soils under Varying Moisture Conditions. Journal of Experimental Biology and Agricultural Sciences, 1, 492-498.

[11] Fernandez, D.P., Neff, J.C., Belnap, J. and Reynolds, R.L. (2006) Soil Respiration in the Cold Desert Environment of the Colorado Plateau (USA): Abiotic Regulators and Thresholds. Biogeochemistry, 78, 247-265. https://doi.org/10.1007/s10533-005-4278-0

[12] Kane, D.A., McFarland, K.N. and Warga, R.M. (2005) Mutations in Half-Baked/ E-Cadherin Block Cell Behaviours That Are Necessary for Teleost Epibody. Development, 132, 1105-1116. https://doi.org/10.1242/dev.01668

[13] Sheng, H.A.O., Yusheng, Y., Yang, Z.J., Chen, G., Nsheng, X.I.E., Gou, J.I.A. and 
Shuangquan, Z. (2010) The Dynamic Response of Soil Respiration to Land-Use Changes in Subtropical China. Global Change Biology, 16, 1107-1121. https://doi.org/10.1111/j.1365-2486.2009.01988.x

[14] Alessandro, A.D., Guerra, I., Anna1, D., Gervasi, A., Harabaglia, P., Luzio, D. and Stellato, G. (2014) Integration of Onshore and Offshore Seismic Arrays to Study the Seismicity of the Calabrian Region: A Two Steps Automatic Procedure for the Identification of the Best Stations Geometry. Advances in Geosciences, 36, 69-75. https://doi.org/10.5194/adgeo-36-69-2014

[15] Lefèvre, R.P., Barré, F.E., Moyano, B.T., Christensen, G. and Bardoux, T. (2014) Higher Temperature Sensitivity for Stable than for Labile Soil Organic Carbon-Evidence from Incubations of Long-Term Bare Fallow Soils. Global Change Biology, 20, 633-640. https://doi.org/10.1111/gcb.12402

[16] Seyfried, M.S. and Rao, P.S.C. (1988) Kinetics of Nitrogen Mineralization in Costa Rican Soils: Model Evaluation and Pretreatment Effects. Plant and Soil, 106, 159-169. https://doi.org/10.1007/BF02371210

[17] Aulen, M., Shipley, B. and Bradley, R. (2012) Prediction of in Situ Root Decomposition Rates in an Interspecific Contest from Chemical and Morphological Traits. Annals of Botany, 109, 287-297. https://doi.org/10.1093/aob/mcr259

[18] Dossa, E.L., Khouma, M., Diedhiou, I., Sene, M., Kizito, F. and Badiane, A.N. (2009) Carbon, Nitrogen and Phosphorus Mineralization Potential of Semiarid Shelian Soils Amended with Native Shrub Residues. Geoderma, 148, 251-260. https://doi.org/10.1016/j.geoderma.2008.10.009

[19] Delphin, J.E. (1988) Utilisation de cinétique du premier ordre en vue de caracétriser la minéralisation de quelques sols agricoles. Agronomie, 8, 289-294. https://doi.org/10.1051/agro:19880402

[20] Davidson, E.A., Janssens, I.A. and Luo, Y.Q. (2006) On the Variability of Respiration in Terrestrial Ecosystems: Moving beyond Q10. Global Change Biology, 12, 154-164. https://doi.org/10.1111/j.1365-2486.2005.01065.x

[21] Fazle, R.S.M., Brian, R., Wilson, P.V., Lockwood, H.D. and Iain, Y.M. (2014) Soil Organic Carbon Mineralization Rates in Aggregates under Contrasting Land Uses. Geoderma, 216, 10-18. https://doi.org/10.1016/j.geoderma.2013.10.023

[22] Kellman, L., Beltrami, H. and Risk, D. (2006) Changes in Seasonal Soil Respiration with Pasture Conversion to Forest in Atlantic Canada. Biogeochemistry, 82, 101-109. https://doi.org/10.1007/s10533-006-9056-0

[23] Frank, A.B., Liebig, M.A. and Tanaka, D.L. (2006) Management Effects on Soil $\mathrm{CO}_{2}$ Efflux in Northern Semiarid Grassland and Cropland. Soil Tillage Research, 89, 78-85. https://doi.org/10.1016/j.still.2005.06.009

[24] Bastida, F., Moreno, J.L., Hernández, T. and García, C. (2006) Microbiological Activity in a Soil 15 Years after Its Devegetation. Soil Biology and Biochemistry, 38, 2503-2507. https://doi.org/10.1016/j.soilbio.2006.02.022

[25] Nkembi, L., Skeen, R. and Ndeloh, D. (2006) The Lebialem Highlands Montane Birds' Conservation Project. Final Report for the Rufford Foundation, UK. Cameroon: ERuDEF. 42 p.

[26] Ayonghe, S.N. and Ntasin, E.B. (2008) The Geological Control and Triggering Mechanism of Landslides of the 20th July 2003 within the Bambouto Caldera, Cameroon. Journal of the Cameroon Academy of Sciences, 7, 191-203.

[27] Zogning, A., Ngouanet, C. and Tiafack, O. (2007) The Catastrophic Geomorphological Processes in Humid Tropical Africa: A Case Study of the Recent Landslide Disasters in Cameroon. Sedimentary Geology, 199, 13-17. 
https://doi.org/10.1016/j.sedgeo.2006.03.030

[28] UCCC (2014) Wabane Council Area. United Councils and Cities of Cameroon. http://www.cvuc.cm/national/index.php/fr/carte-communale/region-du-nord/579wabane

[29] Jiomeneck, P.S.T., Tematio, P., Wilson, M.A. and Yemefack, M. (2011) Andosolization of Soils on a Strombolian Cone at Mount Bambouto, Cameroon. Open Journal of Soil Science, 1, 97-105. https://doi.org/10.4236/ojss.2011.13013

[30] Bitondo, D., Tabi, F.O., Kengmegne, S.S.A., Ngoucheme, M. and Mvondo Ze, A.D. (2013) Micronutrient Concentrations and Environmental Concerns in an Intensively Cultivated Typic Dystrandept in Mount Bambouto, Cameroon. Open Journal of Soil Science, 3, 6. https://doi.org/10.4236/ojss.2013.46033

[31] Wouatong, A.S.L., Eko, R.M., Nankam, M.A., Beyala, V.K.K. and Ekodeck, G.E. (2014) Mineralogy, Geochemistry and Geotechnical Characteristics of Magha Landslides in the Bambouto Caldera, West Cameroon. Journal of Civil Engineering and Science, 3, 35-48

[32] Bouyoucos, G.J. (1962) Hydrometer Method Improved for Making Particle Size Analysis of Soils. Agronomy Journal, 54, 464-465. https://doi.org/10.2134/agronj1962.00021962005400050028x

[33] Walkley, A. and Black, C.A. (1934) An Examination of Digestion Method for Determining Soil Organic Matter and Proposed Modification of the Chromic Acid Titration Method. Soil Science, 37, 29-38. https://doi.org/10.1097/00010694-193401000-00003

[34] Bremner, J.M. and Mulvaney, C.S. (1982) Nitrogen-Total. In: Page, A.L., Ed., Methods of Soil Analysis Part 2, American Society of Agronomy, Madison, 595-624. https://doi.org/10.2134/agronmonogr9.2.2ed.c31

[35] Olsen, R.S. and Sommer, L.E. (1982) Phosphorus. In: Page, A.L., Miller, R.H. and Keeney, D.R., Eds., Methods of Soil Analysis (Part 2), American Society of Agronomy, Madison, 15-72.

[36] Black, C.A., Evans, D.D., White J.L., Ensminger, L.E. and Clark, F.E. (1965) Methods of Soil Analysis (Part 1). Physical and Mineralogical Properties Including Statistics of Measurements and Sampling. American Society of Agronomy Inc., Madison. https://doi.org/10.2134/agronmonogr9.1

[37] Chapman, H.D. (1965) Cation Exchange Capacity. In Black C. A. et al.(eds.). Methods of Soil Analysis, American Society of Agronomy, Madison, Vol. 9, 891-901. https://doi.org/10.2134/agronmonogr9.2.c6

[38] Jain, P., Akula, I. and Edlind, T. (2003) Cycling AMP Signaling Pathway Modulates Susceptibility of Candida Species and Saccharomycescerevisiae to Antifungal Azoles and Other Sterol Biosynthesis Inhibitors. Antimicrobial Agents Chemother, 47, 195-201. https://doi.org/10.1128/AAC.47.10.3195-3201.2003

[39] Vance, E.D., Brookes, P.C. and Jenkinson, D.S. (1987) An Extraction Method for Measuring Soil Microbial, Biomass C. Soil Biology and Biochemistry, 19, 703-707. https://doi.org/10.1016/0038-0717(87)90052-6

[40] Brookes, P.C., Landman, A., Prujer, G. and Jen kinson, D.S. (1985) Chloroform Fumigation and the Release of Soil Nitrogen: A Rapid Direct Extraction Method for Measuring Microbial Biomass Nitrogen in Soil. Soil Biology and Biochemistry, 17, 837-842. https://doi.org/10.1016/0038-0717(85)90144-0

[41] Anderson, T.H. and Domsch, K.H. (1985) Determination of Ecophysiological Maintenance Carbon Requirements of Soil Microorganisms in a Dormant State. Biology and Fertility of Soils, 1, 81-89. https://doi.org/10.1007/BF00255134 
[42] SAS Institute Inc. (2001) SAS/STAT Version 9.1, User's Guide. Cary, 5135 p.

[43] Standford, G. and Smith, S.J. (1972) Nitrogen Mineralization Potentials of Soils. Soil Science Society of America Proceedings, Vol. 36, 465-472. https://doi.org/10.2136/sssaj1972.03615995003600030029x

[44] Murwira, H.K., Kirchmann, H. and Swift, M.J. (1990) The Effect of Moisture on the Decomposition Rate of Cattle Manure. Plant and Soil, 122, 197-199. https://doi.org/10.1007/BF02851975

[45] Bonde, T.A. and Rosswall, T. (1987) Seasonal Variation of Potentially Mineralizable Nitrogen in Four Cropping Systems. Soil Science Society of America Journal, 51, 1508-1514. https://doi.org/10.2136/sssaj1987.03615995005100060019x

[46] Wander, M.M., Traina, S.J., Stinner, B.R. and Peters, S.E. (1994) Organic and Conventional Management Effects on Biologically Active Soil Organic Matter Pools. Soil Science Society Amplified Journal, 58, 1130-1139. https://doi.org/10.2136/sssaj1994.03615995005800040018x

[47] Zhao, R., Coles, N. and Wu, J. (2015) Soil Carbon Mineralization Following Biochar Addition Associated with External Nitrogen. Chilean Journal of Agricultural Research, 75, 465-471. https://doi.org/10.4067/S0718-58392015000500012

[48] Rodríguez-Salgado, I., Pérez-Rodríguez, P., GómezArmesto, A., Díaz-Raviña, M., Nóvoa-Muñoz, J.C., Arias-Estévez, M. and Fernández-Calviño, D. (2017) Carbon Mineralization in Acidic Soils Amended with an Organo-Mineral Bentonite Waste. Journal of Soil Science and Plant Nutrition, 17, 624-634. https://doi.org/10.4067/S0718-95162017000300006

[49] Kumar, M., Kundu, D.K., Ghorai, A.K., Mitra, S. and Singh, S.R. (2018) Carbon and Nitrogen Mineralization Kinetics as Influenced by Diversified Cropping Systems and Residue Incorporation in Inceptisols of Eastern Indo-Gangetic Plain. Soil and Tillage Research, 178, 108-117. https://doi.org/10.1016/j.still.2017.12.025

[50] Mukhopadhyay, S. and Maiti, S.K. (2014) Soil $\mathrm{CO}_{2}$ Flux in Grassland, Afforested Land and Reclaimed Coalmine Overburden Dumps: A Case Study. Land Degradation and Development, 25, 216-227. https://doi.org/10.1002/ldr.1161

[51] Chen, D.D., Zhang, S.H., Dong, S.K., Wang, X.T. and Du, G.Z. (2010) Effects of Land Use on Soil Nutrients and Microbial Biomass of an Alpine Region on the North Eastern Tibetan Plateau. China. Land Degradation and Development, 21, 446-452. https://doi.org/10.1002/ldr.990

[52] Guo, D., Wang, J., Fu, H., Wen, H. and Luo, Y. (2017) Cropland Has Higher Soil Carbon Residence Time than Grassland in the Subsurface Layer on the Loess Plateau, China. Soil and Tillage Research, 174, 130-138. https://doi.org/10.1016/j.still.2017.07.003

[53] Islam, K.R. and Weil, R.R. (2000) Soil Quality Indicator Properties in Mid-Atlantic Soils as Influenced by Conservation Management. Journal of Soil Science Plant Analysis, 29, 2269-2284. https://doi.org/10.1080/00103629809370110

[54] McGonigle, T.P. and Turner, W.G. (2017) Grasslands and Croplands Have Different Microbial Biomass Carbon Levels per Unit of Soil Organic Carbon. Agriculture, 7, 57. https://doi.org/10.3390/agriculture7070057

[55] Desalegn, T., Cruz, F., Kindu, M., Turrión, M.B. and Gonzalo, J. (2014) Land Use/Land-Cover Change and Socioeconomic Conditions of Local Community in the Central Highlands of Ethiopia. International Journal of Sustainable Development and World Ecology, 21, 406-413.

https://doi.org/10.1080/13504509.2014.961181 
[56] Probert, M.E., Dimes, J.P., Keating, B.A., Dalal, R.C. and Strong, W.M. (1998) APSIM's Water and Nitrogen Modules and Simulation of the Dynamics of Water and Nitrogen in Fallow Systems. Agricultural Systems, 56, 1-28. https://doi.org/10.1016/S0308-521X(97)00028-0

[57] Zhang, H. and Zhou, Z. (2018) Recalcitrant Carbon Controls the Magnitude of Soil Organic Matter Mineralization in Temperate Forests of Northern China. Forest Ecosystems, 5, Article No. 17. https://doi.org/10.1186/s40663-018-0137-z

[58] Anderson, T.H. and Domsch, K.H. (2010) Soil Microbial Biomass: The Eco-Physiological Approach. Soil Biology and Biochemistry, 42, 2039-2043. https://doi.org/10.1016/j.soilbio.2010.06.026

[59] Gonzalez-Quinones, V., Stockdale, E.A., Banning, N.C., Hoyle, F.C., Sawada, Y., Wherrett, A.D., Jones, D.L. and Murphy, D.V. (2011) Soil Microbial Biomass-Interpretation and Consideration for Soil Monitoring. Soil Research, 49, 287-304. https://doi.org/10.1071/SR10203

[60] Anderson, T.H. and Domsch, K.H. (1990) Application of Ecophysiological Quotients $\left(\mathrm{qCO}_{2}\right.$ and $\left.\mathrm{Qd}\right)$ on Microbial Biomasses from Soils of Different Cropping Histories. Soil Biology and Biochemistry, 22, 251-255.

https://doi.org/10.1016/0038-0717(90)90094-G

[61] Gil-Sotres, F., Trasar-Cepeda, C., Leirós, M.C. and Seoane, S. (2005) Different Approaches to Evaluating Soil Quality Using Biochemical Properties. Soil Biology and Biochemistry, 37, 877-887. https://doi.org/10.1016/j.soilbio.2004.10.003

[62] Guo, L.B. and Gifford, R.M. (2002) Soil Carbon Stocks and Land Use Change: A Meta-Analysis. Global Change Biology, 8, 345-360. https://doi.org/10.1046/j.1354-1013.2002.00486.x

[63] Klose, S., Wernecke, K.D. and Makeschin, F. (2004) Soil Microbial Biomass and Enzyme Activities in Forest Soils Exposed to Atmospheric Depositions from a Lignite Power Plant. Soil Biology and Biochemistry, 36, 1913-1923. https://doi.org/10.1016/j.soilbio.2004.05.011

[64] Powlson, D.S. (1994) The Soil Microbial Biomass: Before, Beyond and Back. In: Ritz, K., Dighton, J. and Giller, K.E., Eds., Beyond the Biomass, Wiley, Chichester, 3-20. 